\title{
Import Substitution as a Condition for Sustainable Development of Mining Regions
}

\author{
Juraj Janočko, ${ }^{1, *}$,Zuzana Šimková1, Tomas Pavlik ${ }^{1}$, and Inna Pevneva ${ }^{2}$ \\ ${ }^{1}$ Technical University of Kosice, Faculty of Mining, Ecology, Process Control and Geotechnologies, \\ Letná 9, 04200 Kosice, Slovak republic \\ ${ }^{2}$ Kemerovo institute (branch) of Plekhanov Russian University of Economics, Department of \\ Economic Security, Accounting and Audit, 650992 Kuznetsky pr.39, Kemerovo, Russia
}

\begin{abstract}
One of the promising directions for studying the indicators of sustainable development of the extracting region is the analysis of economic trends, the definition and expert evaluation of their values and their practical approval. The assessment of the whole complex of environmental, economic and social indicators of sustainable development is of obvious importance in monitoring, evaluating and adjusting regional targeted programs, developing concepts and programs for long-term socialand-economic development, analyzing their effectiveness. It will allow, if necessary, to correct specific directions of social-and-economic and ecological development of the region. In extracting clusters, the need for the development of an import-substituting machine building cluster is urgent. For its establishing it is necessary to organize an investment consortium of engineering products' consumers, an international network of industry innovation, research-and-production and design firms, a regional agency for attracting and protecting investments in import substitution of industrial products, and a set of tax incentives for residents of the import-substituting cluster.
\end{abstract}

\section{Introduction}

The term "sustainable development" was introduced in wide use by the Prime Minister of Norway G. X. Brundtland who headed the International Commission on Environment and Development in 1987 [1]. Sustainable development in this case was understood as long, continuous, stable, self-sustaining, responsible, safe development, ensuring the satisfaction of the current needs of the living generation without a threat to meeting the needs of future generations.

In the definition of sustainable development by G.H. Brundtland there are no differences between fundamentally distinct concepts of development and growth, which causes difficulties in its use - in his opinion, the development of peoples and countries of the world can continue indefinitely long time, and gross growth is limited by the potential capacity of the ecosphere, its ability to regenerate life support systems. Obviously, understanding sustainable development as "development without growth" will not be

\footnotetext{
* Corresponding author: juraj.janocko@tuke.sk
} 
entirely correct. Therefore, X. Daley takes into account this aspect, which defined sustainable development as "socially sustainable development, in which gross economic growth should not exceed the carrying capacity of life support systems" [2].

R.A. Post in this connection rightly points out that the concept of sustainable development is in fact an attempt to balance the two moral requirements of society: the need to meet the needs of the living generation in economic development and, at the same time, the need to achieve "sustainability" of this development, ensuring that the current generation is not going to "lay down" the future one for the sake of the present [3]. Accordingly, the concept of "sustainability" is interpreted by him as an ongoing process of gradual development from one generation to another, as the level of reasonable well-being and quality of life maintained by generations as long as possible.

\section{Materials and Methods}

Substantially the concept of sustainable development is interdisciplinary and inter-sectoral in nature, including the ecological, economic and social aspects. The ecological component of sustainable development implies ensuring the integrity and viability of biological and physical natural systems, on which, in turn, the global stability of the entire biosphere depends. The economic component is aimed at optimizing the use of natural resources, using environmentally friendly technologies, creating environmentally friendly products, minimizing and processing waste. Finally, the social component implies the development of human capital, the maintenance of social stability, the equitable distribution of resources and opportunities among all members of society, reduction of the number of social conflicts p4-6].

The United Nations Conference on Environment and Development (UNCED) in 1992 recommended that governments of all countries develop their own national strategy for sustainable development. Following this recommendation Russia in 1994 approved the "Main provisions of the state strategy of the Russian Federation for the protection of the environment and sustainable development", and in 1996 adopted the "Concept of the transition of the Russian Federation to sustainable development", which aims to ensure a balanced solution to social-and-economic problems and problems of preservation of a favorable environment and natural and resource potential in order to meet the needs of present and future generations [7-8.

The first criterion for sustainable development in S. Murai's model is population growth of less than $0.5 \%$ per year. Annual growth of $1.0-1.5 \%$ corresponds to the critical level and more than $2 \%$ - to the destructive one [5]. Thus, the lack of population growth or even its decline is an indicator of sustainable development in this model, since it implies the absence of an increase in the anthropogenic load on the biosphere. Taking into account the correlation of the territory and population, the anthropogenic load in the Kemerovo region is relatively small. Whereas Kuzbass is the most densely populated region of Siberia, the density of its population according to data for 2013 was only 28.65 people $/ \mathrm{km} 2$. At the same time, according to the Territorial Body of the Federal State Statistics Service for the Kemerovo Region [5] in Kuzbass since the mid-1990s there has been a natural decline in the population: thus, in 2009 the population of the region was 2773.0 thousand people, and in $2013-2734.1$ thousand people. At the same time, the level of natural population decline is consistently declining - from 2.6 to 0.9 people per 1000 population over the same period. Thus, according to this criterion, the Kemerovo region corresponds to the indicators of the sustainability of development and, at the same time, it demonstrates certain positive changes in the social-and-demographic situation which is even more significant from a strategic point of view [4-5, 9]. 
The second criterion for sustainable development is the annual increase in gross regional product (GRP) from 3 to $5 \%$; the growth of $8-10 \%$ per year is interpreted as critical, more than $10 \%$ or less than 0 - as destructive. According to official statistics, the gross regional product of the Kemerovo region in 2009 was 576 billion rubles, in $2013-$ 767 billion rubles [5]. The average annual increase in GRP calculated on the basis of the data for the indicated years, even with a relative decrease in 2009 and 2012 , was $6.7 \%$ in monetary terms. Taking into account the inflation factor the growth of GDP did not actually exceed the criteria for sustainable development. In the forecast for the development of the region's economy for 2013-2015, the growth of GDP was fixed by 2 to $3 \%$ annually [5]. Respectively, according to this indicator, the Kemerovo region meets the criteria requirements as a whole.

The third criterion is the level of deforestation, not exceeding $0.1 \%$ per year. The deforestation index of $0.5-1.0 \%$ per year is considered critical, more than $1 \%$ - as destructive. According to the "Forest Plan of the Kemerovo Region", for the last interperiod (from 2008 to 2010) the total area of the forest fund lands increased from 5413.5 to 5423.6 thousand hectares, an average of $0.093 \%$ per year; the area covered by forest vegetation - from 5115.4 to 5128.2 thousand hectares, that is, it increased by an average of $0.125 \%$ per year [4]. At the same time, according to the Territorial Body of the Federal State Statistics Service for the Kemerovo Region [4] the scale of artificial reforestation and afforestation demonstrates a noticeable growth - so, the area of afforestation in 2013 compared with the previous year increased by 4.7 times. Consequently, the Kemerovo region clearly meets the requirements of this criterion.

The fourth criterion is the relative area of forests, comprising more than $30 \%$ of the total area. The share of forests $15-20 \%$ is considered as critical, less than $10 \%$ - as destructive. As is known, a specific feature of the Kemerovo region is the wide spread of man-made landscapes, the formation of which is associated with open development of coal and other deposits - in fact, the whole territory from Mezhdurechensk to Anzhero-Sudzhensk is an alternation of coal mines and open pits and waste heaps, concentrating factories, hydraulic structures, etc. As a result of open mining, complex disturbance of lands occurs, and the area disturbed by mining works is at least 64.8 thousand tons. Simultaneously, up to $80 \%$ of the forests are affected by intensive industrial cutting-down [5].

The fifth criterion is the area of farm fields, which is more than 0.3 hectares per person. The area of 0.15 to 0.2 hectares per person in the S. Murai model is critical, less than 0.1 hectares is devastating. According to the Administration of the Kemerovo Region, in general, 2399 thousand hectares of agricultural land are in agricultural turnover, which is $27 \%$ of the total land area of Kuzbass, while the arable land occupies 1483 thousand hectares. The sowing area for the harvest of 2012 was 1048.8 thousand hectares. Respectively, Kuzbass belongs to the regions with a high level of plowing and for each inhabitant of the Kemerovo region there are 0.5 hectares of arable land [10]. Thus the Kemerovo region fully meets the requirements of this criterion of sustainable development.

\section{Results and Discussion}

The problems of weak realization of sustainable development factors in the Kemerovo region's economy are due to its predominantly raw nature, and the lack of manufacturing industries with relatively low impact on the environment.

In the economy of "old industrial" Russian region - the Kemerovo region - despite the high level of urbanization and concentration of basic industries, the problems of import dependence, specific for the entire Russian economy, are deepening. This can be illustrated by the comparative dynamics of coal mining and exports of metal on the one hand, and the import of engineering products on the other (Figure 1). 


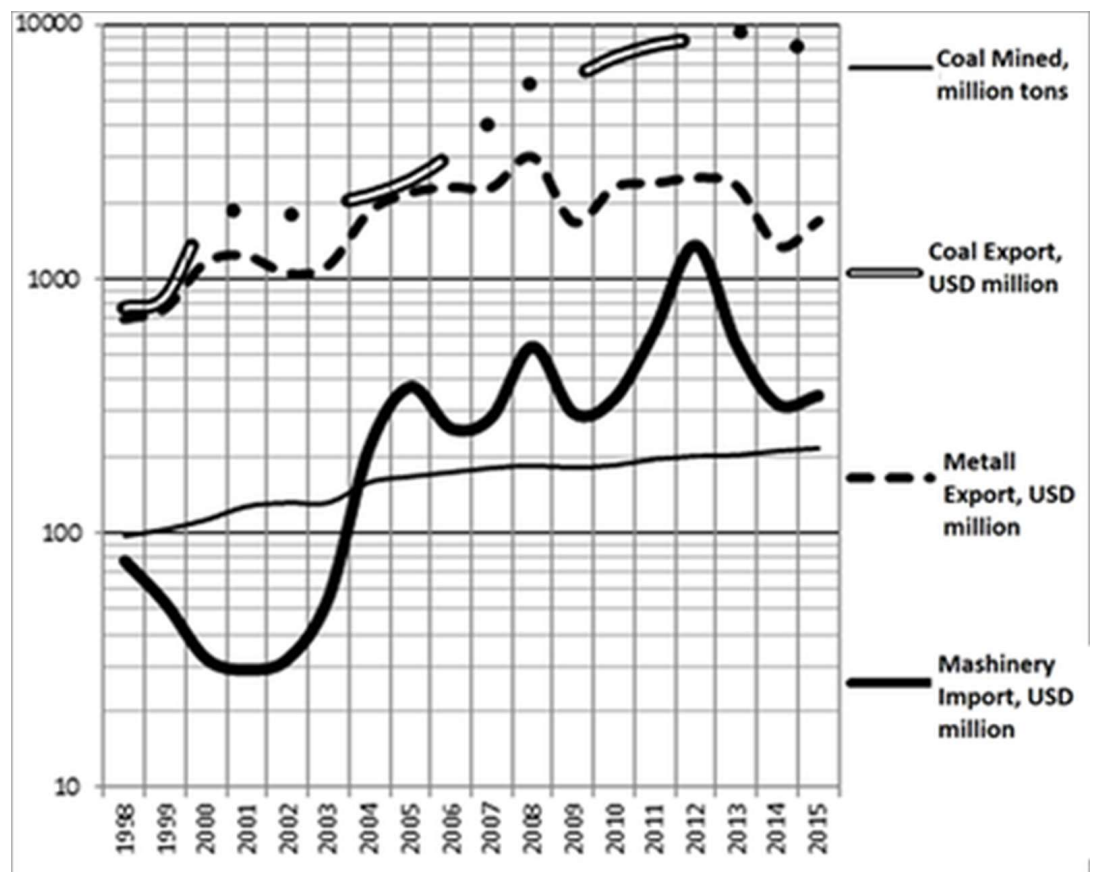

Fig. 1. Comparative dynamics of extraction and exports of raw materials and imports of engineering products in Kuzbass (logarithmic scale).

As follows from the data shown in Fig. 13, the steady growth in coal output in the region (by 109\% over the period 1998-2015) is accompanied, on the one hand, by accelerated replacement of the means of production of coal mines and sections. On the other hand, since 2003, as the consequences of the 1998-1999 devaluation of the ruble having been over, there was a faster growth in the imports of machine-building products in Kuzbass (4 times in 2002-2012). In 2014, a new round of devaluation led to a fall in regional machine-building imports (from $\$ 1,360$ to $\$ 322$ million), but as early as 2015 , its volumes increased by $8 \%$.

At the same time, it is machine building that is the branch on which neo-industrial transformations of the region's economy depend, the starting point of which should be the technological modernization of extractive and basic industries. However, the machinebuilding industry of the Kemerovo region is experiencing significant problems and cannot come out as a "catalyst" for neo-industrial transformation.

The need for import substitution for the Kemerovo region economy is especially acute due to the considerable wear of the domestic means of production used and the predominance of imports in the least worn part of it. Thus, the large equipment of coal mines (excavators, drilling rigs, pumping stations, transformer stations) are worn out by more than $70 \%$, whereas most of the equipment purchased in the last 10 years and having a wear level of less than $30 \%$ is imported.

Meanwhile, in Kuzbass there is a certain reserve for the formation of the institutions necessary for the initiation of neo-industrial import substitution. In particular, the Coordination Center for the Development of Import Substitution has been established in the region and a Regional Plan and a list of investment projects in this area have been created to address regional problems of the development of neo-industrial import substitution. Technological modernization is necessary, first of all, of extractive and basic industries, which, in turn, will create reserve of import substitution of manufacturing and high-tech industries. 
As applied to the Kemerovo region economy, mechanical engineering, particularly its segment, which manufactures products for mining enterprises, rightfully belongs to such an industry. In this regard, we propose the creation of Kuzbass neo-industrial importsubstituting cluster, focused on the following tasks:

1. Deep reconstruction, technical and technological modernization of the region's industrial enterprises, a large part of which was created in the 1960s and 1970s and has the depreciation average level of fixed capital about $70 \%$.

2. Breaking-off the endless circle of investment and production problems: significant physical wear and tear of fixed capital - a decrease in the international competitiveness of machine-building products - a reduction in sales volumes - a lack of investment resources for the modernization of production - further increase in physical wear and tear. This requires the formation of an Investment Program for the regional machine-building industry, reflecting the needs of the coal, chemical, metallurgical industries in the region in new equipment.

3. Increasing the degree of cooperation of machine-building enterprises in the region, which today is estimated at less than $10 \%$ and overcoming their technological disunity. An important prerequisite for the development of cooperative relations within the cluster is the presence in the region of the Association of Machine-builders of Kuzbass, which unites about thirty companies in the Kemerovo, Novosibirsk and Tomsk regions.

To form a neo-industrial import-substituting machine-building cluster in Kuzbass, we consider the following to be necessary.

First, to draft a development strategy for this cluster, linking investment in the technical re-equipment of coal, chemical and engineering industries, instrumentation, government support and guarantees for attracting long-term loans.

Second, to make the list of residents of the cluster, including both machine-building enterprises and the subjects of the financial and scientific, research and educational spheres of the region, as well as foreign developers of modern machine-building technologies and software.

Third, to provide the institutional support for the creation of an import-substituting cluster in the region:

- the organization of an investment consortium, which should include the main consumers of engineering products - enterprises of coal, chemical, machine-building industries;

- the organization of a regional Agency for attracting and protecting investments in the import substitution of machine-building products;

- the organization of a guarantee fund for investments in engineering, the main role in which the regional administration should play.

Four, to make the list of regional taxes benefits provided to residents of the machine building cluster.

\section{Conclusion}

Thus, the outcome of the mining region on the trajectory of sustainable development requires the initiation of a neo-industrial import substitution. To do this, it is important to form innovation-industrial clusters of a special type - a network, in which enterprises and research organizations from different clusters should be integrated into a single research and production complex based on the technological platform of import substitution. As the uniting elements the innovation and production infrastructure, as well as investment projects for the production of import-substituting products, covering all residents of the cluster should act. 


\section{References}

1. G. X. Brundtland, Sustainable development (Lagard, Stockholm, 1988)

2. X. Daley, Sustainable Future (Mills Pub., Chicago, 1993)

3. R. A. Post, Nature and Society (Dome Pub., Los Angeles, 2001)

4. S. Zhironkin, M. Gasanov, G. Barysheva, K. Kolotov, O. Zhironkina, 15, 03012 (2017)

5. A. B. Efremenkov, A. A. Khoreshok, S. A. Zhironkin, A. V. Myaskov, IOP Conference Series: Earth and Environmental Science, 50:1, 012009 (2017)

6. C. Goldin, Katz L., American Economic Review, LVII, 524 - 531 (1967)

7. I. Ketata, W. Sofka, C. Grimpe, R\&D Management, 45:1, 60-75 (2015)

8. B. Sály, J. Janocko, S. Jacko, V. Jureňa, I. Hlavaty, New results in the mature east slovakian basin based on $3 D$ and $2 D$ seismic data interpretation and sequence stratigraphy, Society of Petroleum Engineers, 68th European Association of Geoscientists and Engineers Conference and Exhibition, incorporating SPE EUROPEC 2006, Opportunities in Mature Areas (EAGE, 2006)

9. B. Lundvall, Nation system of innovation. Towards a theory of innovation and interactive learning (Pinter Publishers, London, 1992)

10. V. Frolova, O. Dolina, T. Shpil'kina, E3S Web of Conf., 21, 04018 (2017) 